Eingereicht am 28. Februar 1991

[1] D. Seebach, S.G. Müller, U. Gysel, J. Zimmermann, Helv. Chim. Acta 1988, 71, 1303; D Seebach, D. Blaser, U. Gysel, J. N. Kinkel, ibid., in Vorbereitung.

[2] Neuste Übersichten und Anwendungensbeispiele von Cellulose-triacetat und Cellulose-tribenzoat J. N. Kinkel, K. Reichert, P. Knöll, GIT Supplement 1989, 3, 104; R. Isaksson, P. Erlandsson, L. Hansson, A. Holmberg, S. Berner, J. Chromatogs: 1990, 498, 257; A. Mannschreck, B Stephan, H. Zinner, F. Kastner, Chimia 1990,44, 336.

[3] Kandidaten für das Zwischenprodukt sind i-iii. Bei der Reaktion entsteht l equiv. HBr. Falls ii in einer Bootkonformation vorliige, wäre das cisDerivat stabiler als das trans-Derivat!

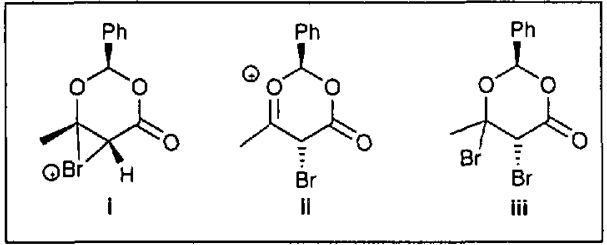

[4] a) D. Scebach, J. Zimmermann, U. Gysel, R. Ziegler, T.-K. Ha, J. Am. Chem. Soc. 1988, 110 4763 ; b) J. Zimmermann, D. Seebach, Helv. Chim. Acta 1986, 69, 1147; c) D. Seebach, W. Amberg, Chem. Ber. 1990, 123, 2413.
[5] D. Seebach, R. Imwinkelried, G. Stucky, Helv. Chim. Acla 1987, 70, 448

[6] a) R. U. Lemieux, Can. J. Chem. 1951, 29,415; b) Sereck-Hanssen, Ark. Kemi 1957, 10, 135, 146; c) M. M. Schemyakin, Y. A. Ovichinnikov, V.T. Ivanov, P. V. Kosterskii, Zh. Ohshch. Khim. S.S.S.R. 1967, 37, 2617

[7] Am Beispiel des racemischen Dioxinons 1 zeigten wir, dass das mit $\mathrm{Me}_{2} \mathrm{CuLi}$ erhaltene Derivat rac$5\left(\mathrm{R}=\mathrm{CH}_{3}\right)$ durch Epimerisierung an Kieselgel teilweise ins cis-Derivat 2-epi-rac-5 $\left(\mathrm{R}=\mathrm{CH}_{3}\right)$ übergeführt werden kann, dessen 'H-NMRSpektrum mil demjenigen vom 5-epi-5 (aus $(R)$ 3-Hydroxybuttersäure [5]) verglichen wurde; dabei stellte sich heraus, dass die Spektren identisch sind (für das $\mathrm{H}-\mathrm{C}(2)$ ist in [5] ein falscher Wert der chemischen Verschicbung angegeben; die korrekte Zahl ist $\delta=6,28 \mathrm{ppm})$.

[8] Im Falle der (tert-Butyl)-methyl-dioxinone hatten wir auch stets trans-Produkte erhalten [4].

19] D. Seebach, M.Züger, Helv. Chim. Acta 1982.65, 495; D. Seebach, M. A. Sutter, R. H. Weber, M F. Züger, Osg. Synth. 1984, 63, I. Die Enantiomerenreinheit von $8, \mathrm{R}=\mathrm{CH}_{3}$, beträgt It. ${ }^{14} \mathrm{~F}$ NMR-Spektrum des Mosher-Esters $90 \%$.

[10] R.O. Duthaler, A. Hafner. M. Riediker, Pure Appl. Chem. 1990, 62,613; R. Noyori, M. Kitamura, in 'Modern Synthetic Methods', Ed. R. Scheffold, Springer Verlag, Heidelberg, 1989, S. 115; R. Noyori, M. Kitamura, S. Okada, S. Suga, J. Am. Chem. Soc. 1989, $/ 1 /, 4028 ;$ R. W. Hoffmann, S. Dresly, J. W. Lanz, Chem. Ber, 1988, /21, 1501; M. Braun, Angen'. Chem.1987,99, 24; ibid. Int.
Ed 1987, 26, 24: D Seebach, S. Rogro, J Zimmermann, in 'Stereochemistry of Organic and Bioorganic Transformations, Workshop Conlerences Hocthst, Ed. W. Bartmann und K.B. Sharpless, VCH Verlagsgesellschaft, Weinheim, 1987, Vol. 17, S. 85; R. W. Hoffmann. S. Dresly, Angen'. Chem. 1986, 98, 186; ihid.Im. Ed. 1986. 25. 189: C. H. Heathcock, in 'Asymmetric Synthesis, Stercodifferentiating Addition Reactions". Ed. J. D. Morrison, Academic Press, Sin Diego, 1984, Part B. Bd. 3, S. 111; D.A. Evans, J.V. Nelson, T.R. Taber, Topirs Stereorehem. 1982, 13,1

[11] D. Seebach, W. Amberg, Chem. Ber. 1990, 123, 2429.

[12] 'Organikum', 15. Aufl. VEB Deutscher Verlag der Wissenschaften, 1981, S. 623.

[13] S.C. Watson, J. F. Easthan, J. Orgamemet. Che'm. $1967,9,165$.

[14] W. C. Still, M. Kathn, A. Mitra, I. Org. Chem. $1978,43,2923$

[15] M. Sato, K. Sekiguchi, H. Ogasawara, Ch. Kalneko, Synthesis 1985, 224.

[16] E. V. Dehmlow, A. R. Schamoul, Liehigs. Ann. Chem. 1982, 1753: E. V. Dehmlow. A. Sleegers, Z. Neturforsch., B 1988, 43, 912, s. Fussnole [2].

[17] V.Schurig. H.P. Nowomy, I.Chromatogr. 1988. $441,155$.

Chimia 45 (1991) 117-121

(c) Schweiz. Chemiker-Verband; ISSN 0009-4293

\title{
Potentiometric Detector for Capillary Zone Electrophoresis
}

\author{
Carsten Haber, Ivo Silvestri, Stephan Röösli, and Wilhelm Simon*
}

Abstract. The use of a potentiometric microelectrode as an end-column detector in capillary zone electrophoresis (CZE) is described. Uncoated fused silica capillaries with an internal diameter (I. D.) of $25 \mu \mathrm{m}$ are used. The microelectrode is placed a few micrometers behind the capillary end. Due to its high internal resistance $\left(10^{8}-10^{11} \Omega\right)$, special devices to decouple the potentiometric detector from the electrophoretic current are not necessary. The composition of the liquid membrane of the microelectrode was especially designed to show a good response for most cations except magnesium, which was used as a background electrolyte. Separations are carried out at potentials ranging from 15 to $20 \mathrm{kV}$. With this method, alkali and alkali earth metals are successfully separated and directly detected down to concentrations of $c a \cdot 10^{-7}-10^{-8} \mathrm{~mol} / 1$.

\section{Introduction}

Since the early 1980's, capillary zone electrophoresis has received considerable attention in the domain of analytical separations. A major area of interest within this technique is in the development of new detectors. Since the use of very narrow cap-

*Correspondence: Prof. Dr. W. Simon Swiss Federal Institute of Technology (ETH) Department of Organic Chemistry

Universitatstrasse 16

$\mathrm{CH}-8092 \mathrm{Zürich}$ illaries is advantageous due to lower Joule heat production, higher separation efficiency and speed of analysis [1], good sensitivity in small detection volumes is desired. Column I.D.'s typically range between 25 and $150 \mu \mathrm{m}$, resulting in detection volumes from $3 \mathrm{nl}$ to $10 \mathrm{pl}$, assuming a path width of one capillary I. D.

Since a great number of separated molecules absorb UV radiation, more than $90 \%$ of all capillary electrophoresis applications are based on photometric detection methods at present. The UV detection follows Lambert-Beer's law and is strongly dependent on the pathlength of absorbing material. The detection limit of a strongly absorbing substance in a $100-\mu \mathrm{m}$ capillary (signal-to-noise ratio 2) reaches $10^{-6} \mathrm{~mol} / \mathrm{l}$ [2] but detcriorates drastically, as the column I. D. drops. Fluorescent detection is a more sensitive and selective detection method, but is limited to molecules that have the ability to emit fluorescence light. The highest sensitivities are reported to be at a level of $10^{4} \mathrm{~mol} / \mathrm{l}$ of methotrexate in a $75-\mu \mathrm{m}$ capillary (signalto-noise ratio 3) [3]. Recently, Zare and coworkers reported detection limits of $10^{11}$ $\mathrm{mol} / \mathrm{l}$ for amino acids labeled with fluorescein isothiocyanate [18]. Wallingford and Ev'ing describe an amperometric detector consisting of an ultrafine carbon fiber inserted into the end of the column [4]. Detection is limited to electroactive molecules. Measurable signals for serotonin at $8.5 \times 10^{4} \mathrm{~mol} /$ $I$ in a $12.7-\mu \mathrm{m}$ capillary are reported [5]. Zare and coworkers [6] introduced an oncolumn conductivity detector, consisting of two Pt wires ( $25 \mu \mathrm{m}$ O.D.) fixed in diametrically opposite holes in 50 or $75 \mu \mathrm{m}$ I.D. fused silica capillary tubing. The apparatus reaches detection limits of c $a .10^{7} \mathrm{~mol} / \mathrm{l}$ for Li [6].

A major drawback in using electrochemical as opposed to optical detectors in CZE is the difficulty of electrical isolation from the high voltage power supply. Special devices for fused silica capillaries like porous glass joints [4] and on-column frits [7] have to be applied to create a current-free zone at the detection end, where the clectrochemical sensor is placed. En'ing and Zare 
Eingereicht am 28. Februar 1991

[1] D. Seebach, S.G. Müller, U. Gysel, J. Zimmermann, Helv. Chim. Acta 1988, 71, 1303; D Seebach, D. Blaser, U. Gysel, J. N. Kinkel, ibid., in Vorbereitung.

[2] Neuste Übersichten und Anwendungensbeispiele von Cellulose-triacetat und Cellulose-tribenzoat J. N. Kinkel, K. Reichert, P. Knöll, GIT Supplement 1989, 3, 104; R. Isaksson, P. Erlandsson, L. Hansson, A. Holmberg, S. Berner, J. Chromatogs: 1990, 498, 257; A. Mannschreck, B Stephan, H. Zinner, F. Kastner, Chimia 1990,44, 336.

[3] Kandidaten für das Zwischenprodukt sind i-iii. Bei der Reaktion entsteht l equiv. HBr. Falls ii in einer Bootkonformation vorliige, wäre das cisDerivat stabiler als das trans-Derivat!

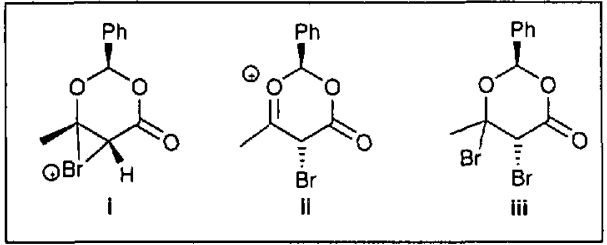

[4] a) D. Scebach, J. Zimmermann, U. Gysel, R. Ziegler, T.-K. Ha, J. Am. Chem. Soc. 1988, 110 4763 ; b) J. Zimmermann, D. Seebach, Helv. Chim. Acta 1986, 69, 1147; c) D. Seebach, W. Amberg, Chem. Ber. 1990, 123, 2413.
[5] D. Seebach, R. Imwinkelried, G. Stucky, Helv. Chim. Acla 1987, 70, 448

[6] a) R. U. Lemieux, Can. J. Chem. 1951, 29,415; b) Sereck-Hanssen, Ark. Kemi 1957, 10, 135, 146; c) M. M. Schemyakin, Y. A. Ovichinnikov, V.T. Ivanov, P. V. Kosterskii, Zh. Ohshch. Khim. S.S.S.R. 1967, 37, 2617

[7] Am Beispiel des racemischen Dioxinons 1 zeigten wir, dass das mit $\mathrm{Me}_{2} \mathrm{CuLi}$ erhaltene Derivat rac$5\left(\mathrm{R}=\mathrm{CH}_{3}\right)$ durch Epimerisierung an Kieselgel teilweise ins cis-Derivat 2-epi-rac-5 $\left(\mathrm{R}=\mathrm{CH}_{3}\right)$ übergeführt werden kann, dessen 'H-NMRSpektrum mil demjenigen vom 5-epi-5 (aus $(R)$ 3-Hydroxybuttersäure [5]) verglichen wurde; dabei stellte sich heraus, dass die Spektren identisch sind (für das $\mathrm{H}-\mathrm{C}(2)$ ist in [5] ein falscher Wert der chemischen Verschicbung angegeben; die korrekte Zahl ist $\delta=6,28 \mathrm{ppm})$.

[8] Im Falle der (tert-Butyl)-methyl-dioxinone hatten wir auch stets trans-Produkte erhalten [4].

19] D. Seebach, M.Züger, Helv. Chim. Acta 1982.65, 495; D. Seebach, M. A. Sutter, R. H. Weber, M F. Züger, Osg. Synth. 1984, 63, I. Die Enantiomerenreinheit von $8, \mathrm{R}=\mathrm{CH}_{3}$, beträgt It. ${ }^{14} \mathrm{~F}$ NMR-Spektrum des Mosher-Esters $90 \%$.

[10] R.O. Duthaler, A. Hafner. M. Riediker, Pure Appl. Chem. 1990, 62,613; R. Noyori, M. Kitamura, in 'Modern Synthetic Methods', Ed. R. Scheffold, Springer Verlag, Heidelberg, 1989, S. 115; R. Noyori, M. Kitamura, S. Okada, S. Suga, J. Am. Chem. Soc. 1989, $/ 1 /, 4028 ;$ R. W. Hoffmann, S. Dresly, J. W. Lanz, Chem. Ber, 1988, /21, 1501; M. Braun, Angen'. Chem.1987,99, 24; ibid. Int.
Ed 1987, 26, 24: D Seebach, S. Rogro, J Zimmermann, in 'Stereochemistry of Organic and Bioorganic Transformations, Workshop Conlerences Hocthst, Ed. W. Bartmann und K.B. Sharpless, VCH Verlagsgesellschaft, Weinheim, 1987, Vol. 17, S. 85; R. W. Hoffmann. S. Dresly, Angen'. Chem. 1986, 98, 186; ihid.Im. Ed. 1986. 25. 189: C. H. Heathcock, in 'Asymmetric Synthesis, Stercodifferentiating Addition Reactions". Ed. J. D. Morrison, Academic Press, Sin Diego, 1984, Part B. Bd. 3, S. 111; D.A. Evans, J.V. Nelson, T.R. Taber, Topirs Stereorehem. 1982, 13,1

[11] D. Seebach, W. Amberg, Chem. Ber. 1990, 123, 2429.

[12] 'Organikum', 15. Aufl. VEB Deutscher Verlag der Wissenschaften, 1981, S. 623.

[13] S.C. Watson, J. F. Easthan, J. Orgamemet. Che'm. $1967,9,165$.

[14] W. C. Still, M. Kathn, A. Mitra, I. Org. Chem. $1978,43,2923$

[15] M. Sato, K. Sekiguchi, H. Ogasawara, Ch. Kalneko, Synthesis 1985, 224.

[16] E. V. Dehmlow, A. R. Schamoul, Liehigs. Ann. Chem. 1982, 1753: E. V. Dehmlow. A. Sleegers, Z. Neturforsch., B 1988, 43, 912, s. Fussnole [2].

[17] V.Schurig. H.P. Nowomy, I.Chromatogr. 1988. $441,155$.

Chimia 45 (1991) 117-121

(c) Schweiz. Chemiker-Verband; ISSN 0009-4293

\title{
Potentiometric Detector for Capillary Zone Electrophoresis
}

\author{
Carsten Haber, Ivo Silvestri, Stephan Röösli, and Wilhelm Simon*
}

Abstract. The use of a potentiometric microelectrode as an end-column detector in capillary zone electrophoresis (CZE) is described. Uncoated fused silica capillaries with an internal diameter (I. D.) of $25 \mu \mathrm{m}$ are used. The microelectrode is placed a few micrometers behind the capillary end. Due to its high internal resistance $\left(10^{8}-10^{11} \Omega\right)$, special devices to decouple the potentiometric detector from the electrophoretic current are not necessary. The composition of the liquid membrane of the microelectrode was especially designed to show a good response for most cations except magnesium, which was used as a background electrolyte. Separations are carried out at potentials ranging from 15 to $20 \mathrm{kV}$. With this method, alkali and alkali earth metals are successfully separated and directly detected down to concentrations of $c a \cdot 10^{-7}-10^{-8} \mathrm{~mol} / 1$.

\section{Introduction}

Since the early 1980's, capillary zone electrophoresis has received considerable attention in the domain of analytical separations. A major area of interest within this technique is in the development of new detectors. Since the use of very narrow cap-

*Correspondence: Prof. Dr. W. Simon Swiss Federal Institute of Technology (ETH) Department of Organic Chemistry

Universitatstrasse 16

$\mathrm{CH}-8092 \mathrm{Zürich}$ illaries is advantageous due to lower Joule heat production, higher separation efficiency and speed of analysis [1], good sensitivity in small detection volumes is desired. Column I.D.'s typically range between 25 and $150 \mu \mathrm{m}$, resulting in detection volumes from $3 \mathrm{nl}$ to $10 \mathrm{pl}$, assuming a path width of one capillary I. D.

Since a great number of separated molecules absorb UV radiation, more than $90 \%$ of all capillary electrophoresis applications are based on photometric detection methods at present. The UV detection follows Lambert-Beer's law and is strongly dependent on the pathlength of absorbing material. The detection limit of a strongly absorbing substance in a $100-\mu \mathrm{m}$ capillary (signal-to-noise ratio 2) reaches $10^{-6} \mathrm{~mol} / \mathrm{l}$ [2] but detcriorates drastically, as the column I. D. drops. Fluorescent detection is a more sensitive and selective detection method, but is limited to molecules that have the ability to emit fluorescence light. The highest sensitivities are reported to be at a level of $10^{4} \mathrm{~mol} / \mathrm{l}$ of methotrexate in a $75-\mu \mathrm{m}$ capillary (signalto-noise ratio 3) [3]. Recently, Zare and coworkers reported detection limits of $10^{11}$ $\mathrm{mol} / \mathrm{l}$ for amino acids labeled with fluorescein isothiocyanate [18]. Wallingford and Ev'ing describe an amperometric detector consisting of an ultrafine carbon fiber inserted into the end of the column [4]. Detection is limited to electroactive molecules. Measurable signals for serotonin at $8.5 \times 10^{4} \mathrm{~mol} /$ $I$ in a $12.7-\mu \mathrm{m}$ capillary are reported [5]. Zare and coworkers [6] introduced an oncolumn conductivity detector, consisting of two Pt wires ( $25 \mu \mathrm{m}$ O.D.) fixed in diametrically opposite holes in 50 or $75 \mu \mathrm{m}$ I.D. fused silica capillary tubing. The apparatus reaches detection limits of c $a .10^{7} \mathrm{~mol} / \mathrm{l}$ for Li [6].

A major drawback in using electrochemical as opposed to optical detectors in CZE is the difficulty of electrical isolation from the high voltage power supply. Special devices for fused silica capillaries like porous glass joints [4] and on-column frits [7] have to be applied to create a current-free zone at the detection end, where the clectrochemical sensor is placed. En'ing and Zare 
[8] described recently a method for coupling electrochemical detectors directly to the separation capillary, however, with losses in sensitivity and additional extra column band broadening.

In this paper, we describe the use of a potentiometric microelectrode as end-column detector in CZE. Due to its high internal resistance $\left(10^{8}-10^{11} \Omega\right)$, this type of sensor is suitable to detect inorganic cations in doubly distilled $\mathrm{H}_{2} \mathrm{O}$ by placing it directly at the end of the separation capillary while operating at potentials up to $20 \mathrm{kV}$.

\section{Theory}

In recent years, we published several articles describing the use of the potentiometric microelectrode as an on-column detector in HPLC [9-12]. The major advantage of this sensor is its ability to respond to extremely small amounts of ions. Tip diameters of easily pulled micropipettes are usually in the range of $I \mu \mathrm{m}$, resulting in tip areas of $8 \times 10^{13} \mathrm{~m}^{2}$. Assuming a spherical diffusion layer with a thickness of approximately one tip diameter $(1 \mu \mathrm{m})$, a detection volume of $26 \times 10^{-15} \mathrm{I}$ is obtained [12].

The electromotive force (emf) of a potentiometric cell assembly of the type

\section{$\mathrm{Ag} ; \mathrm{AgCl}, 3 \mathrm{M} \mathrm{KCl}$ reference electrode}

$$
\begin{gathered}
\text { sample } \\
\text { solution }
\end{gathered}
$$

selectivity and $K_{i j}^{\text {pol }}>1$ describes a higher preference of the sample ion $\mathrm{j}$ against the background ion i (with $K_{\mathrm{ij}}^{\mathrm{pot}}=1 / K_{\mathrm{ij}}{ }^{\mathrm{pol}}$ ). In a real electrophoretic measurement, the height of a peak arises from the relative difference of the electromotive forces between the eluting component and the background electrolyte (Fig. I).

$\left.\Delta E=2.303 \frac{R T}{z F} \log \left[\left(\left(a_{\mathrm{i}}-a_{\mathrm{j}}\right)+K_{\mathrm{ij}}^{\text {pot }} a_{\mathrm{j}}\right) / a_{\mathrm{i}}\right)\right]$

Eqn. 2. underscores the effect that the relative difference of the electromotive forces is strongly dependent on the activities of the components $\mathrm{i}$ and $\mathrm{j}$ and their relative selectivity ratios. The selectivity coefficient and activity of the buffer ion determine the sensitivity of the whole system. This fact is illustrated by Fig. 2. The so-called ideal ionselective electrode prefers one single ion and discriminates the interfering ions. In contrast, the ideal ISE detector prefers all ions except the one that is used as the background electrolyte. In this way, two different detection modes are possible and are distinguished by the value of the selectivity coefficient: $l$ ) the direct method, by measuring the emf signals directly against a background ion having a low selectivity relative to the sample ions (Fig. 2,a) and 2) the in-

with two monovalent ions $i$ and $j$ of the same charge in the sample solution can be approximated by the Nicolsky-Eisenman equation [13][14]

$$
E=E_{0}+2.303 \frac{R T}{z F} \log \left(a_{\mathrm{i}}+K_{\mathrm{ij}}^{\text {pot }} a_{\mathrm{j}}\right)
$$

where $E$ is the emf of the cell assembly $[\mathrm{mV}], \mathrm{E}_{0}$ is a potential difference comprising a constant plus the liquid junction potential at the reference electrolyte/sample solution interface [mV], $2.303 R T / F=59.16 \mathrm{mV}$ at $25^{\circ}, z$ is the charge of the ions $i$ and $\mathrm{j}, a_{\mathrm{j}}$ is the activity of the sample ion $\mathrm{j}[\mathrm{mol} / \mathrm{l}], a_{\mathrm{i}}$ is the activity of the background ion $\mathrm{i}[\mathrm{mol} / \mathrm{l}]$, and $K_{i j}^{p o x}$ is the selectivity factor. $K_{i j}^{p o n}<1$ means that the background ion $i$ is preferred over sample ion $\mathrm{j}, K_{i j}^{\text {put }}=1$ is the case of equal

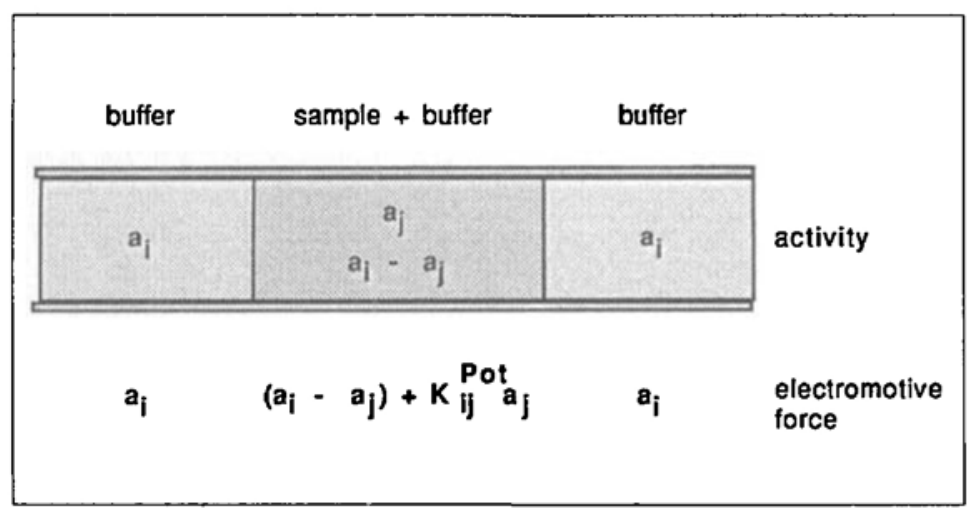

Fig. 1. Sumple zone with activity a, in a buffer electrolyte of activity $a_{i}$
Fig. 3. Detection limits for direct and indirect potentiometric detection. according to Eqn. 2, with selectivity factors ranging from $10^{4}$ (direct mode) $1010^{-4}$ (indirect ground ion $\mathrm{a}_{1}=10^{3} \mathrm{moll}$ mode): activity of hack- direct method [19], by measuring negative emf signals arising from a displacement of background ions, having a high selectivity relative to the sample ions (Fig. 2, b).

Fig. 3 compares the detection limits of the direct and the indirect method. According to Eqn. 2, detection limits with direct detection $\left(K_{i j}^{\text {pol }}>1\right)$ will always be lower than for indirect detection $\left(K_{\mathrm{ij}}^{\mathrm{pot}}<1\right)$.

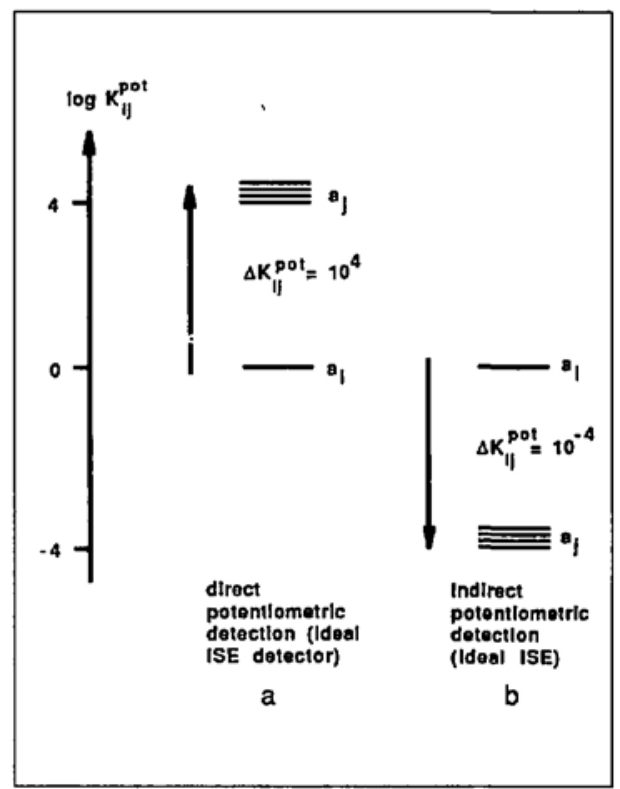

Fig. 2. Ideal ISE and ideal ISE-derector. $a_{1}$, activity of sample ion; $a_{1}$, activity of background ion: $K^{\text {ixy }}$, selectivity factor (measure of the preference of the sample ion $\mathrm{j}$ over the background ion $\mathrm{i}$ by the sensor)

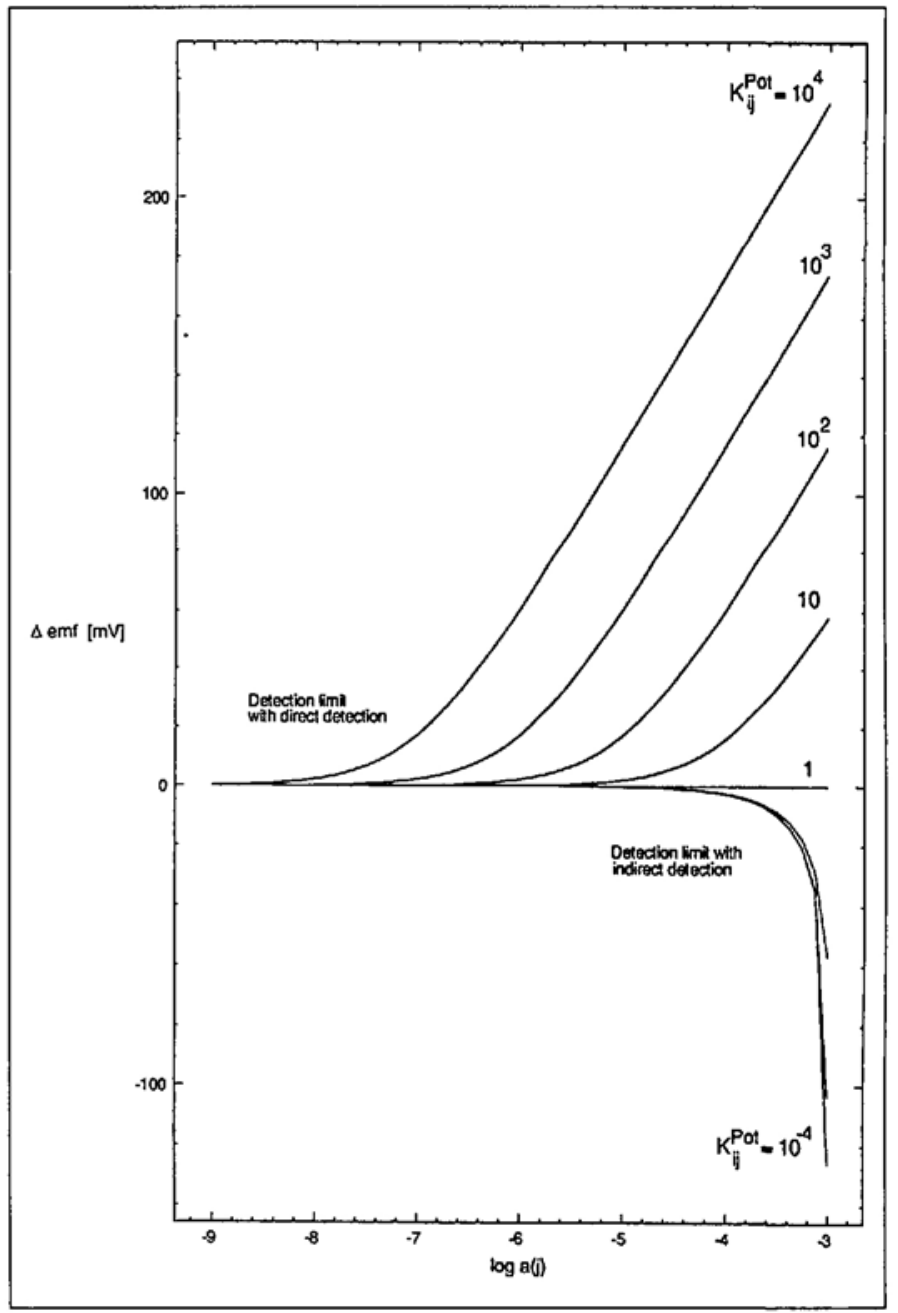




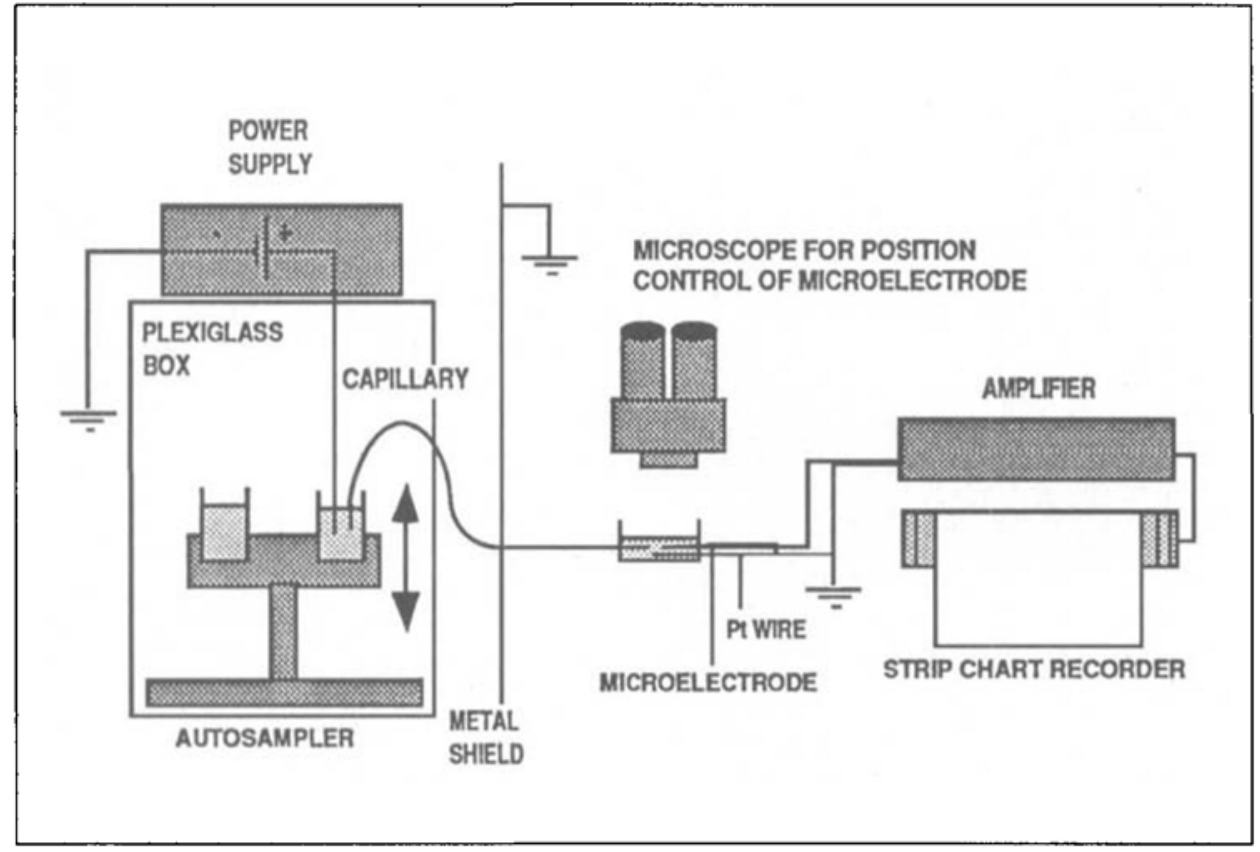

Fig. 4. Capillary electrophoresis system with potentiometric detection

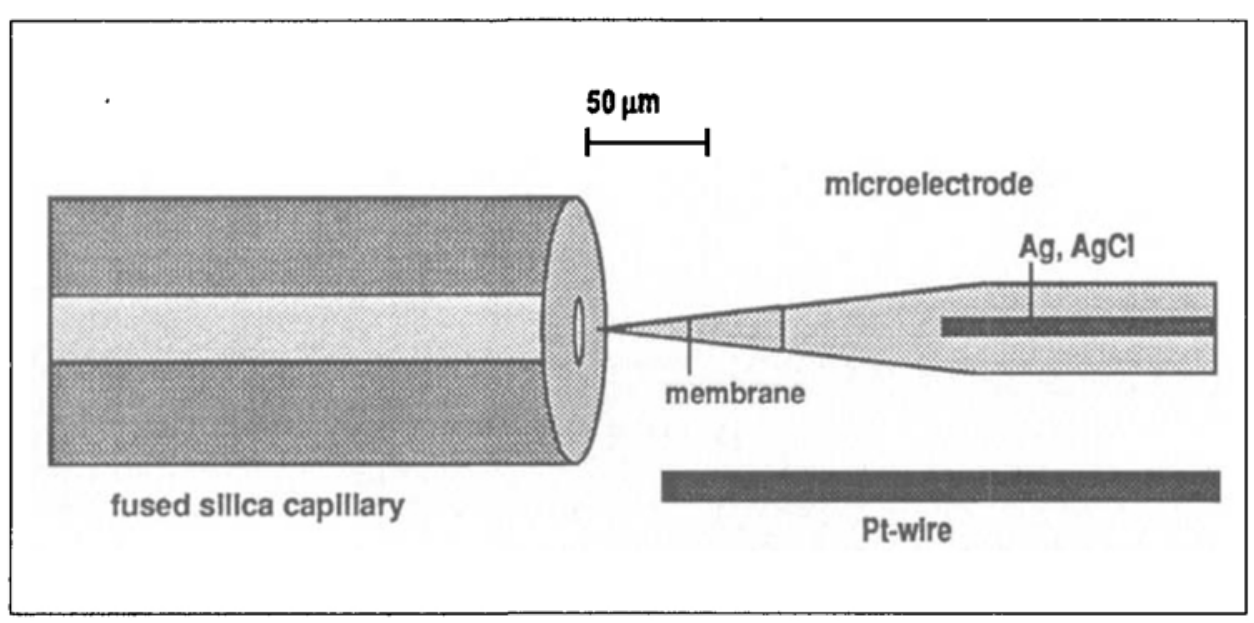

Fig. 5. Position of the microelectrode and the Pt wire at the column end

\section{Experimental}

\subsection{Electrophoretic System}

The electrophoretic system is shown in Fig. 4. It consists of a high-voltage power supply (model 205A 5OR, Bertan Associates Inc., Hicksville, NY 11801) providing a voltage up to $50 \mathrm{kV}$ and a remote autosampler (model 624 and control unit 643, Fa. Metrohm AG. Herisau, Switzerland) to switch between sample and buffer solns. Some metallic pieces of the autosampler were replaced by plastic, to ensure the absence of metallic material near the high-voltage end. The highvoltage electrode ( $\mathrm{Pt}$ wire) and the autosampler were placed in a plexiglass box, to protect the operator. Separations were carried out in uncoated fused silica capillaries of $25 \mu \mathrm{m}$ I.D. (Scientific Glass Engineering, Ringwood, Australia). The microelectrode, the $\mathrm{Pt}$ wire and the end of the fused silica capillary are placed in a small plexiglass vessel that contained the buffer soln. The whole detection cell was housed in a Faraday cage to reduce external noise. For the movement of the microelectrode, a mechanical micromanipulator (Wild Leitz $A G, \mathrm{CH}-8021$ Zürich) was used and for the position control a microscope (Invertoskop D, Carl Zeiss $A G, \mathrm{CH}-8032 \mathrm{Zürich})$ together with a TV camera and monitor (Carl'Leiss AG / Philips AG, CH-802I Zürich). The position control in the horizontal plane was carried out by comparing the sharpness of focus of the electrode tip and the capillary end. The best position of the tip of the microclectrode was found to be some microns beyond the end of the capillary (Fig. 5). The potential difference was measured between the ion-selcctive microelectrode and a Pt wire that served also to ground the detection vessel. To reduce the noise to a minimum, the signal from the high-impedance sensor had to be transformed into a low-impedance signal as close as possible to the source. Therefore, an impedance-converter (AD 515KH, Analog Devices, Norwood, MA, USA; input-impedance $10^{13} \Omega / 1.6 \mathrm{pF}$ differential, $10^{15}$ $\Omega / 0.8 \mathrm{pF}$ common mode; leak current at the input < $100 \mathrm{fA}$; capacity elimination) was coupled directly to the internal reference half-cell of the potentiometric microelectrode. The signal was transmitted via special isolated cables to an FD 223 dual electrometer (World Precision (nstruments). The signals were recorded with a four channel strip chart recorder $(W+W$ recorder model 314. Kontron AG, CH-8040 Zürich). The current was constantly monitored by putting a resistor of $10^{4} \Omega$ between the Pt wire and ground, and the IR drop was measured with a multimeter (I79 TRMS Digital Multimeter, Keithley Instruments, Taunton, MA, USA).

\subsection{Membrane Phase of the Ion-Selective Microelec-} trode

The membrane cocktail consists of a $1 \%(w / w)$ soln of the neutral ionophore bis(N,N-diphenyl)-1,2phenylenebis(oxy-2,1-ethanediyl)bis(oxyacetamide) (Fig. 6, see also [15]) together with 68.5 mol-\% (relative to the ionophore, $100 \%$ ) of potassium tetrakis(4from FlukaChemie AG, Buchs, Switzerland). The major advantage of this membrane (originally used as a $\mathrm{Ba}-$ selective membrane, see also [15]) is its 'bad' response to magnesium and hydrogen ions (Fig. 6). By choosing chlorophenyl)borate in 2-nitrophenyl octyl ether (both

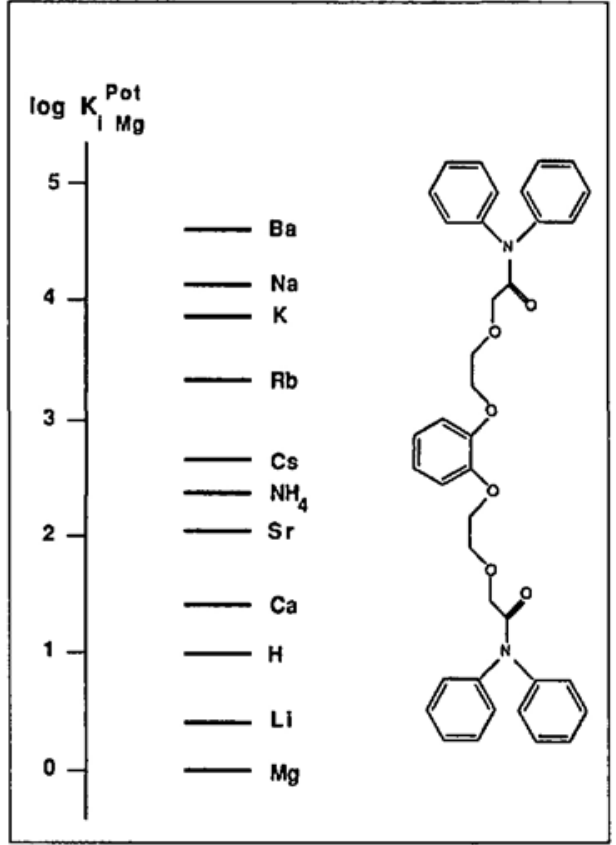

Fig. 6. Selectivity coefficichts and comstimution of bis(N,N-diphenyl)-I.2-phenylenebis(oxy-2.I-ethanediyl)his(oxyacetamide) as ohtained hy separate selution method [17] (0.1 $\mathrm{M}$ solutions). Composition of the membrane cocktail: $1 \%$ ionophore $(100 \mathrm{~mol}-\%), 68.5$ mol-\% of potassium tetrakis(4-chlorophenyl) borate in 2-nitrophenyl octyl ether.

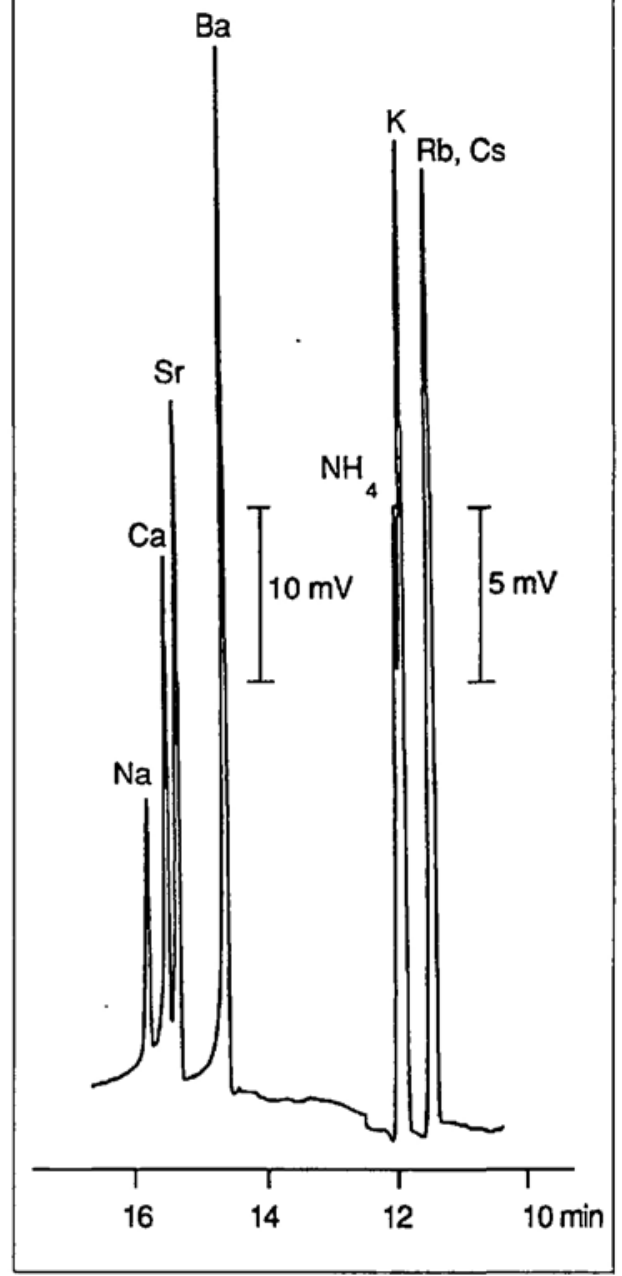

Fig. 7. Electropherogram of a solution containing 10" m alkali and alkali-earth metals. Capillary I.D. $25 \mu \mathrm{m}$; length $0.99 \mathrm{~m}$; buffer $20 \mathrm{~ms}$ magnesium acetate: $\mathrm{pH}$ 7.5; injection electrokinetically, $5000 \mathrm{~V}$ for $2 \mathrm{~s}$; potential $15 \mathrm{kV}$; ISE membrane as described previously; detection post-column. 
CHIMLA $4.5(1491) \mathrm{Nr} .4$ (April)

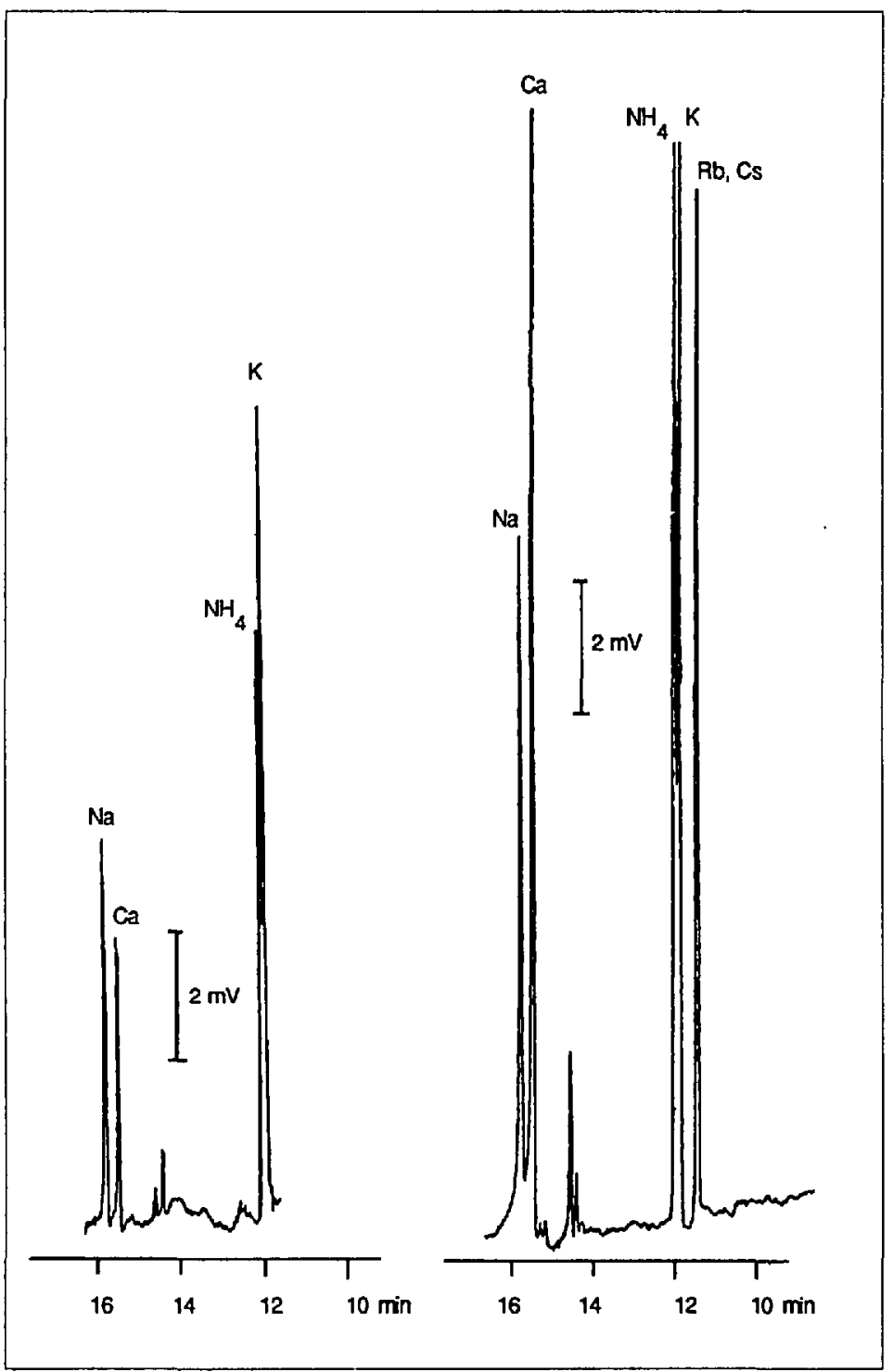

Fig. 8. Comparison of the quality of deiomized (left) and doubly distilled water from a wushbottle (right) by free zone electrophoresis. Capillary I.D. $25 \mu \mathrm{m}$; length $0.99 \mathrm{~m}$; buffer $20 \mathrm{~mm}$ magnesium acetate; $\mathrm{pH} 7.5$; injection electrokinetically, $5000 \mathrm{~V}$ for $4 \mathrm{~s}$; potential $15 \mathrm{kV}$; ISE membrane as described previously; detection post-column.

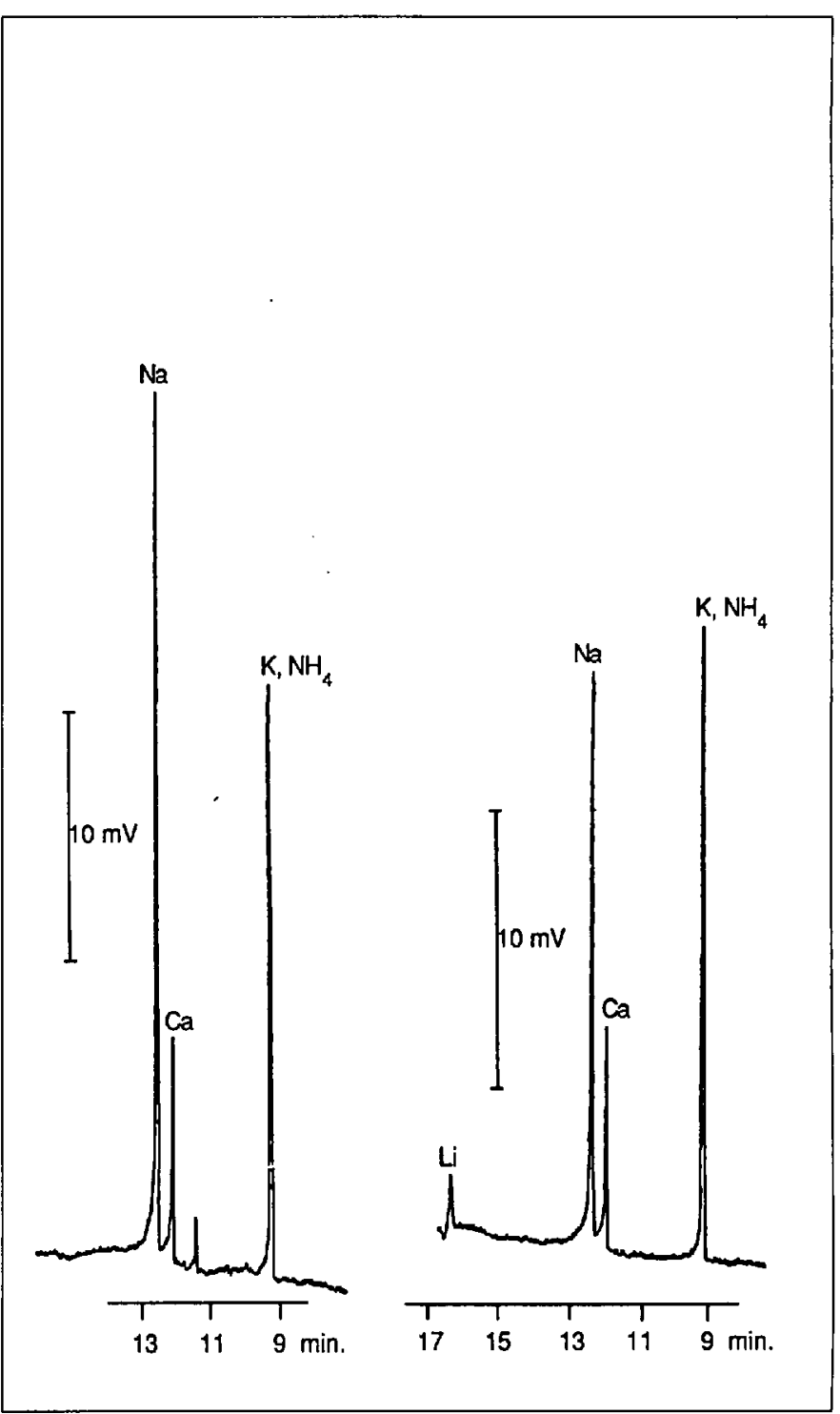

Fig. 9. Free zone electropherogram of deionized (left) and doubly distilled nater (right) at pH 5.14. Capillary I.D. $25 \mu \mathrm{m}$; length $0.99 \mathrm{~m}$; buffer $20 \mathrm{~mm}$ magnesium acetate (HCl); injection electrokinetically, $5000 \mathrm{~V}$ for $5 \mathrm{~s}$; potential $20 \mathrm{kV}$; ISE membrane as described previously; detection post-column. magnesium acetate as buffer electrolyte, the mobile phase showed an extremely low potential and the eluting sample zones of the different cations (all from Fluka Chemic $A G$, Buchs, Switzerland) could be detected with the sensitivity according to their relative selectivity-ratios to magnesium (Eqn. 2).

The internal filling electrolyte consisted of $\mathrm{MgCl}_{2}$. The concentration of magnesium was chosen to be the same as in the background electrolyte. In this way, diffusion processes across the membrane phase could be eliminated and a constant baseline was obtained.

\subsection{Preparation of the Ion-Selective Microelectrode}

The preparation, pulling procedure and silanization of the glass micropipettes has been described in [16]|17|. The micropipelte was filled with a $20 \mathrm{~mm}$ soln. of $\mathrm{MgCl}_{2}$. A slight pressure onto the back-end of the glass body was applied to fill the tip with soln. Then, the front of the micropipette was clipped into the membrane cocktail. By applying a short vacuum pulse onto the back-end of the glass body, the nembrane phase was sucked into the tip (front filling technique). The length of the filled zone was between 100 and $300 \mu \mathrm{m}$.

\section{Applications}

With the previously described system and the ISE sensor, we studied some aqueous solutions containing alkali and alkali earth metals by free zone electrophoresis. Separations were carried out in fused silica capillaries of $25 \mu \mathrm{m}$ I.D. with magnesium acetate as background electrolyte. Sample injections were performed electrokinetically simply by applying a certain voltage over a short time period onto the vessel containing the sample solution. The signals were measured in a differential mode against a $\mathrm{Pt}$ wire in the detector cell. We observed that under the high-voltage conditions in CE the $\mathrm{Pt}$ reference is in terms of noise and signal stability (drift) superior to the calomel reference. Fig. 7 shows an electropherogram of a solution containing $10^{-5} \mathrm{~mol} / \mathrm{l}$ alkali and alkali earth metals. The integrals of the ionpeaks behave in accordance with their individual selectivity coefficients relative to $\mathrm{Mg}$ (note that the range was switched after 13 min). The half-width of the Ba signal corresponds to 893,000 theoretical plates. It is important to understand that the ISE signal follows a logarithmic function and, therefore, the peaks are displayed broader than they would appear to be in linear scale [12] The electropherograms shown in Figs. 8-10 are some studies on the quality of deionized and doubly distilled $\mathrm{H}_{2} \mathrm{O}$ and illustrate very clearly the analytical power of this sytem.
Solutions were injected by electromigration. The separations were performed at 15 and $20 \mathrm{kV}$. Although we expected a drop in the sensitivity with decreasing $\mathrm{pH}$, we still obtained considerably high signals; up to 30 $\mathrm{mV}$ for $\mathrm{CE}$ runs at $\mathrm{pH} 5.14$ (magnesium acetate $/ \mathrm{HCl}$ ). An interesting result is the appearance of a $\mathrm{Li}$ peak in doubly distilled deionized $\mathrm{H}_{2} \mathrm{O}$, but not in the original deionized $\mathrm{H}_{2} \mathrm{O}$ (Fig. 9). Furthermore, we observed that the doubly distilled $\mathrm{H}_{2} \mathrm{O}$ from washbottles was more contaminated. This contamination comes not from the plastic material, but from the absorption of aerosols, as the surrounding air gets re-aspirated through the tip of the washbottle.

A problem was the determination of the detection limit. Since all the $\mathrm{H}_{2} \mathrm{O}$ samples we analyzed contained traces of $\mathrm{Na}^{+}, \mathrm{K}^{+}, \mathrm{NH}_{4}^{+}$, and $\mathrm{Ca}^{++}$, we monitored the $\mathrm{K}^{+}$signal from a $10^{-5} \mathrm{M}$ solution by diluting it to $10^{-10} \mathrm{M}$. We found that the height of the signal did not change anymore at a concentration of $10^{-7}$ $10^{-8} \mathrm{M}$. It has to be pointed out that the detection limit depends strongly on the selectivity ratio of the individual cation relative to $\mathrm{Mg}$. 


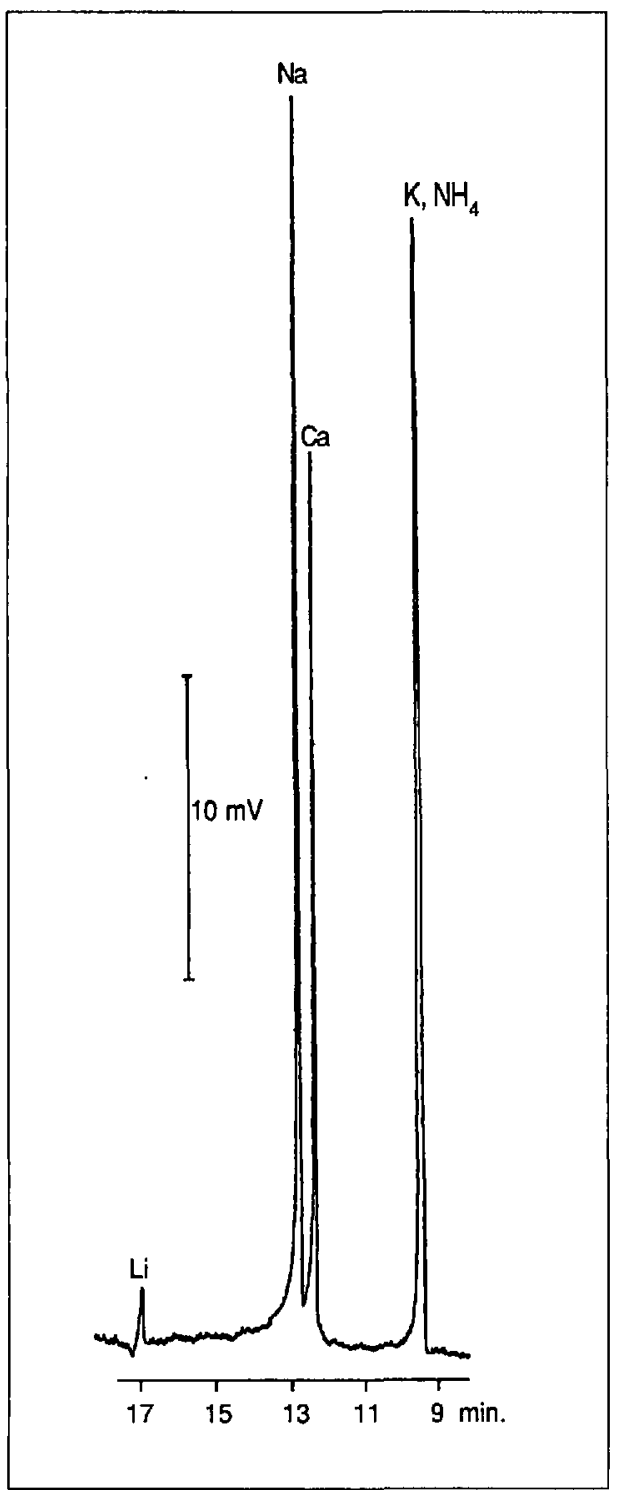

\section{Conclusion}

In this contribution, we have presented some of the first successful results of the combination CZE-ISE. With its low detection limits for various cations, the ISE is a powerful sensor for charged species. Due to its high internal resistance, this sensor is almost perfectly suitable as a detector in zone electrophoresis. To fully exploit the analytical possibilities of this method, efforts are in progress to extend this technique to anions and organic cations.

We would like to thank Steven West from Orion Research for helpful discussions. This work was partly supported by the Swiss National Science Foundation.

Fig. 10. Free zone electropherogram of doubly distilled water stored in a washbottle. Capillary I.D. $25 \mu \mathrm{m}$; length $0.99 \mathrm{~m}$; buffer $20 \mathrm{~mm}$ magnesium acetate $(\mathrm{HCl})$; injection electrokinetically, $5000 \mathrm{~V}$ for $5 \mathrm{~s}$; potential $20 \mathrm{kV}$; ISE membrane as described previously; detection postcolumn.
CHIMIA $+5(1491)$ Nr. 4 |Apriil\}

Received: March 15, 1991

[1] E. Grushka, R. M. McCormick, J. J. Kirhland, Anal. Che'm. 1989, 6/, 241.

[2] Y. Walbroel, J. W. Jorgenson, J. Cirrmumenel. 1984, 315, 135 .

[3] M. C. Roach, P. Gozel, R. N. Zare, J. Chromatogr. 1988, 426, 129

[4] R. A. Wallingford, A. G. Ewing, Anal. Chem. $1987,59,1762$

[5] R. A. Wallingford, A. G. Ewing, Anal. Chem. 1988, 60, 1972

[6] X. Huang, TK. Pang, M. J.Gordon, R. N.Zare, Anal Chem. 1987, 59, 2747.

[7] X. Huang, R. N. Zare, Anal Chom. 1990, 6?, 443.

[8] X. Huang, R. N. Zare, S. Sloss, A. G. Ewing, Anal. Chem. 1991, 63, 189.

19] A. Manz, W. Simon, J. Chromatogr. 1987 , 387, 187.

[10] A. Manz, W. Simon, Mikrerhim. Actu 1986, I, 147.

[11] A. Manz, W. Simon, Anal. Chem. 1987,59, 74.

[12] A. Manz, W. Simon, J.Chromalogr. Sci. 1983, $21,326$.

[13] G. Eisemman, 'Glass Electrodes for Hydrogen and Other Cations', MarcelDekker, New York, 1967.

[14] R. A. Durst, 'Ion-Selective Electrodes', Special Publication No. 314, National Bureatu of Standards, Washington, DC. 1969.

[15] F. Vögtle, F Bongardt, T Klciner M W Läubli, O. Dinten, E. Pretsch, W. Simon, Anal. Chem. 1985, 57, 2756.

[16] F. Lanter, Dissertition 7076, ETH-Zürich. 1982.

[17] T. Bührer, Dissertation 8984, ETH-Zürich, 1989.

[18] J. V. Sweedler, J. B. Shear, H. A. Fishman. R. N. Zare, Anal Chem. 1991, 03, 496.

[19] A. Jeanjaquet, W. G. Kuhr, Abstracts of papers, '2nd International Symposium on HighPerformance Capillary Electrophoresis', San Francisco, CA, 1990, Abstract P 101.

\section{(S)-Trolox ${ }^{T M}$ Methyl Ether: a Powerful Derivatizing Reagent for the GC Determination of the Enantiomers of Aliphatic Alcohols}

\section{Willy Walther')*, Walter Vetter ${ }^{1}$ ), Max Vecchi' $)^{\dagger}$, Heinz Schneider ${ }^{2}$ ), Robert Karl Müller $^{2}$ ), and Thomas Netscher $\left.{ }^{2}\right)^{*}$}

Abstract. (S)-Trolox ${ }^{T M}$ methyl ether 5a prepared from the racemic commercial antioxidant Trolo $x^{T M}$ is presented as a new chiral reagent for the GC analysis of stereoisomeric primary and secondary alcohols. The superiority to the hitherto known reagents is demonstrated by some examples.

\section{Introduction}

New methods of stereoselective organic synthesis, particularly some involving homogeneous asymmetric catalysis [1], yield products with high enantiomeric excess. For the development and the improvement of such techniques, reliable analytical procedures for ee determinations are essential.

In the course of our work aimed at the total synthesis of naturally occurring tocopherols 1 and other isoprenoids, we realized that general methods for the exact determination of the (high) optical purity of intermediates comprising Me-branched $\mathrm{C}-\mathrm{C}$ chains were lacking. Thus, we developed a practical GC method for the stereochemical analysis of acyclic terpenoid carbonyl compounds using acetals derived from (+)-Ltartaric esters [2].

In the case of Me-branched primary alcohols, we could obtain no satisfactory result by the application of commercially available chiral reagents. Recently, reports on the direct separation of a few such alcohols on GC columns coated with (chiral) cyclodextrine derivatives have appeared [3]. In this communication, we would like to offer a promising new derivatizing reagent for the analysis of such alcohols using conventional (achiral) GC columns.

\footnotetext{
*Correspondence: W. Walther, Dr. Th. Netscher 1) Central Research Units

2) Department of Vitamin and Nutrition Research F. Hoffmann-La Roche Lud.
}

$\mathrm{CH}-4002$ Basel 